\title{
KARAKTERISTIK PENDERITA RETARDASI MENTAL DI SLB KOTA BUKITTINGGI
}

\author{
Raysa Ramayumi ${ }^{1}$, Adnil Edwin Nurdin², Siti Nurhajjah ${ }^{3}$
}

\begin{abstract}
Abstrak
Retardasi mental merupakan keadaan perkembangan jiwa yang terhenti atau tidak lengkap yang dikarakteristikkan dengan tingkat IQ dibawah 70-75. Frekuensi penderita retardas mental pada laki-laki lebih tinggi. Retardasi mental dapat disebabkan oleh aspek biologis yang mencakup gangguan kromosom dan genetik. Sindrom Down merupakan salah satu bentuk retardasi mental berat yang terkait dengan usia ibu saat hamil. Penelitian ini bertujuan untuk mengetahui karakteristik penderita retardasi mental di SLB Kota Bukittinggi. Penelitian ini menggunakan rancangan deskriptif dengan jumlah sampel sebanyak 50 orang yang diambil dengan teknik random sampling. Data dikumpulkan melalui data dasar siswa berupa jenis kelamin dan usia ibu saat hamil serta tes IQ yang kemudian dikategorikan berdasarkan derajat retardasi mental Hasil dari penelitian ini dengan 46 sampel yang memenuhi kriteria inklusi didapatkan bahwa frekuensi laki-laki dengan perempuan sama, $41,3 \%$ termasuk derajat retardasi mental ringan, dan $34,8 \%$ dari ibu penderita hamil pada usia lebih dari 35 tahun. Berdasarkan hasil penelitian disimpulkan bahwa sebagian penderita memiliki derajat retardasi mental ringan, dengan usia ibu saat hamil pada usia lebih dari 35 tahun.
\end{abstract}

Kata kunci: retardasi mental, jenis kelamin, derajat retardasi mental, usia ibu saat hamil

\begin{abstract}
Mentally retardated is a state of mental development stalled or incomplete which characterized by an IQ level below 70-75. Frequency mentally retarded of male is higher. Mentally retardated caused by biological aspects that include chromosomal and genetic disorders. Down syndrome is a severe form of mentally retardated associated with maternal age. This study aims to investigate the characteristics of individuals with mentally retardated at special school in Bukittinggi. This study used a descriptive design and 50 people with random sampling. Data was collected through student basic data such as gender and maternal age and IQ tests were then categorized based on the degree of mentally retardated. The results of 46 samples that complied inclusion criteria was found that the frequency of male same with female, $41.3 \%$ including the degree of mild mentally retardated, and $34.8 \%$ of maternal age is over than 35 years old. This study concluded that most individuals have a mild degree of mentally retardated, with maternal age is over than 35 years old.
\end{abstract}

Keywords: mentally retardated, sex, degree of mentally retardated, maternal age

Afiliasi Penulis : Mahasiswa Fakultas Kedokteran Universitas Andalas, 2. Bagian Kedokteran Jiwa Fakultas Kedokteran Universitas Andalas, 3. Bagian Anatomi Fakultas Kedokteran Universitas Andalas. Korespondensi : Raysa Ramayumi, email: raysa.ramayumi@yahoo.com, telp: 081374353777 


\section{PENDAHULUAN}

Retardasi mental merupakan ketidakmampuan yang dikarakteristikkan dengan keterbatasan signifikan baik dalam fungsi intelektual dan perilaku penyesuaian diri yang diekspresikan dalam konseptual diri, sosial, dan kemampuan beradaptasi. Penderita retardasi mental mulai terlihat pada usia sebelum 18 tahun, dengan karakteristik retardasi mental yaitu fungsi intelektual dibawah rata-rata $(\mathrm{IQ}<70-75) .{ }^{1}$

Definisi retardasi mental yang digunakan di Indonesia adalah definisi menurut Pedoman Penggolongan dan Diagnosis Gangguan Jiwa (PPDGJ) III yaitu suatu keadaan perkembangan jiwa yang terhenti atau tidak lengkap, yang terutama ditandai oleh terjadinya hendaya keterampilan selama masa perkembangan. Hendaya keterampilan ini berpengaruh pada tingkat kecerdasan secara menyeluruh. ${ }^{2}$

Prevalensi penderita retardasi mental $1-3 \%$ pada populasi umum. ${ }^{3}$ Insiden retardasi mental 1,5 kali lebih banyak pada laki-laki dibandingkan dengan perempuan, dimana kejadian tertinggi pada masa anak sekolah dengan puncak usia 6 sampai 17 tahun. $^{3}$

Menurut data Sensus Nasional Biro Pusat Statistik 2003 jumlah penyandang cacat di Indonesia sebesar 0,7\% dari jumlah penduduk Indonesia. Data dari World Health Organization (WHO) jumlah anak berkebutuhan khusus di Indonesia adalah sekitar $7 \%$ dari total jumlah anak usia 0-18 tahun atau sebesar 6.230.000 pada tahun $2007 .{ }^{4}$

Retardasi mental dapat disebabkan oleh aspek biologis yang mana mencakup gangguan kromosom dan genetis, penyakit infeksi dan penggunaan alkohol pada saat ibu hamil. ${ }^{5}$ Etiologi retardasi mental lain dijelaskan bahwa termasuk multifaktorial, artinya banyak faktor yang berperan dalam terjadinya retardasi mental ini, dan semuanya saling mempengaruhi. 3,6

Abnormalitas kromosom merupakan salah satu penyebab yang paling sering ditemukan dari kasus retardasi mental. Sekitar 40\% kasus retardasi mental derajat berat disebabkan oleh kelainan pada kromosomnya, sedangkan frekuensi abnormalitas kromosom pada kasus retardasi mental derajat ringan sekitar $10 \%$. Kelainan kromosom yang banyak ditemukan pada penderita retardasi mental adalah trisomi, yang sering melibatkan kromosom 13, 18, dan $21{ }^{7}$

Sindrom Down merupakan salah satu bentuk retardasi mental berat, yang secara genetik terjadi kelainan pada jumlah kromosom 21 dengan prevalensi 14 kejadian per 10.000 kelahiran. $^{8}$ Insiden sindrom Down yang ditemukan oleh Sadler sekitar 1 dari 2000 konseptus pada wanita usia $<25$ tahun, dan meningkat seiring dengan usia ibu dimana pada usia 35 tahun menjadi 1 dalam 300 dan 1 dalam 100 pada usia 45 tahun. $^{9}$

Retardasi mental yang sering muncul setelah sindrom Down yakni sindrom Fragile $X$, dimana terjadi mutasi gen pada kromosom $X$ sehingga pada laki-laki yang hanya memiliki satu kromosom $X$ akan berdampak lebih parah dibandingkan perempuan yang memiliki dua kromosom X. ${ }^{5}$ Laki-laki dengan sindrom ini biasanya memperlihatkan retardasi mental sedang sampai berat dan memiliki angka hiperaktifitas yang tinggi. 
Berdasarkan kriteria diagnostik yakni hasil test intelegensi, DSM IV mengklasifikasikan retardasi mental berdasarkan tingkat keparahannya dimana penderita dengan IQ 50-70 (ringan), 35-50 (sedang), 20-35 (berat), dan $<20$ (sangat berat). Sebagian besar anak dengan retardasi mental (sekitar $85 \%$ ) berada pada taraf ringan, $10 \%$ pada taraf sedang, 3-4\% pada taraf berat dan sisanya $1-2 \%$ pada taraf retardasi sangat berat. ${ }^{5}$

Berdasarkan kebijakan Direktorat Pendidikan Luar Biasa, Departemen Pendidikan Nasional menggolongkan pendidikan untuk anak tuna grahita berdasarkan nilai / skor IQnya, yaitu SLB C untuk anak tuna grahita ringan (dengan IQ 50-70) dan SLB C1 untuk anak tuna grahita sedang (dengan IQ 30-50).

Menurut data yang diperoleh dari Dinas Pendidikan Provinsi Sumatera Barat tahun 2014, terdapat 121 lembaga SLB baik negeri maupun swasta. Jumlah siswa didik yang terdata yaitu SDLB 4.567 orang, SMPLB 456 orang, dan SMALB 234 orang. ${ }^{10}$

Sampai saat ini belum ada data tentang distribusi penderita retardasi mental di Sumatera Barat khususnya Kota Bukittinggi. Berdasarkan hal ini, maka peneliti tertarik untuk melakukan penelitian mengenai distribusi penderita retardasi mental baik dari segi jumlah penderita berdasarkan jenis kelamin dan derajat retardasi mental, serta distribusi usia ibu saat hamil pada penderita retardasi mental sebagai salah satu etiologi retardasi mental pada siswa retardasi mental di Sekolah Luar Biasa (SLB) Kota Bukittinggi.

\section{METODE}

Penelitian ini merupakan penelitian deskriptif. Penelitian ini dilaksanakan di 3 SLB di Kota Bukittinggi, yakni SLB Gantiang, SLB Al-Azhar, dan SLB Restu Ibu dalam kurun waktu 10 bulan dari Januari-November 2014.

Populasi penelitian adalah penderita retardasi mental yang bersekolah di SLB Kota Bukittinggi. Besar sampel berjumlah 50 orang. Teknik pengambilan sampel yang digunakan adalah Random Sampling, dimana dari 152 sampel, akan dipilih secara acak 50 sampel untuk diikutsertakan dalam penelitian.

Prosedur dalam penelitian ini adalah dengan menggunakan data dasar siswa berupa nama siswa, jenis kelamin, dan usia ibu saat hamil yang telah tersedia di SLB. Usia ibu saat hamil, nantinya akan dikategorikan dalam 5 kelompok, yaitu usia <20 tahun, 20-25 tahun, 26-30 tahun, 31-35 tahun, dan $>35$ tahun.

Hasil test IQ didapatkan dari pemeriksaan IQ menggunakan CFIT (Culture Fair Intellegence Test) yang dilakukan oleh psikolog di SLB masingmasing, dan hasil tersebut akan dikategorikan menjadi derajat retardasi mental yaitu ringan dengan IQ 50-55 sampai 70-75, sedang dengan IQ 35-40 sampai 50-55, berat dengan IQ 20-25 sampai $35-40$ dan IQ dibawah 20 termasuk dalam derajat retardasi sangat berat.

\section{HASIL DAN PEMBAHASAN}

Penelitian telah dilakukan pada 50 sampel yang dipilih acak dari 152 orang penderita retardasi mental yang bersekolah di 3 SLB di Kota Bukittinggi. 
Dari 50 sampel tersebut, terdapat 4 sampel yang drop out karena tidak tuntas dalam pemeriksaan IQ sehingga penilaian tidak dapat dilakukan.

Tabel 1 Distribusi karakteristik penderita retardasi mental

\begin{tabular}{lc}
\hline Karakteristik & $\mathrm{f}(\%)$ \\
& $\mathrm{n}=46$ \\
\hline Usia & $13(28,3)$ \\
6-10 tahun & $29(63)$ \\
$11-15$ tahun & $4(8,7)$ \\
16-20 tahun & \\
Jenis Kelamin & $23(50)$ \\
$\quad$ Laki-Laki & $23(50)$ \\
$\quad$ Perempuan & \\
Derajat Retardasi Mental & \\
Rata-rata bawah $(>75)$ & $9(19,6)$ \\
Ringan (50-55 s/d 70- & $23(50)$ \\
75) & $7(15,2)$ \\
Sedang (35-40 s/d 50- & $7(15,2)$ \\
55) & 0 \\
Berat $(20-25 \mathrm{~s} / \mathrm{d}$ 35-40) & \\
Sangat berat $(<20)$ & \\
\hline
\end{tabular}

Tabel 2 Distribusi usia ibu saat hamil pada penderita retardasi mental

\begin{tabular}{lc}
\hline Usia ibu saat hamil & $\mathrm{f}$ \\
\hline$<20$ tahun & $0(0)$ \\
$20-25$ tahun & $6(13,1)$ \\
$26-30$ tahun & $10(21,7)$ \\
$31-35$ tahun & $14(30,4)$ \\
$>35$ tahun & $16(34,8)$ \\
\hline
\end{tabular}

Karakteristik usia penderita retardasi mental dari penelitian ini diketahui bahwa frekuensi tertingi adalah pada kelompok usia 10-13 tahun sebanyak 22 orang $(47,8 \%)$. Hasil penelitian tersebut sejalan dengan penelitian yang dilakukan Dian Ramawati pada tahun 2011 di SLB Kabupaten banyumas, dimana usia penderita retardasi mental terbanyak di sekolah pada rentang usia 12,26 sampai dengan 13,58 tahun, ${ }^{11}$ serta sesuai dengan kepustakaan yang menyatakan bahwa insiden tertinggi penderita retardasi mental dalah usia 10 sampai 14 tahun. $^{12}$
Hasil penelitian mengenai karakteristik jenis kelamin didapatkan bahwa $50 \%$ responden laki-laki dan 50\% perempuan. Hasil penelitian ini berbeda dengan penelitian yang pernah dilakukan pada tahun 2008 oleh Preodita Agradi pada 61 anak di SLB Negeri Semarang, dimana diperoleh hasil anak berjenis kelamin laki-laki sebanyak $85,2 \%$ dan perempuan $14,8 \%,{ }^{13}$ begitu juga penelitian yang dilakukan oleh Dian Ramawati di tahun 2011, yang memperoleh hasil bahwa dari 65 sampel ditemukan 40 berjenis kelamin laki-laki $(61,5 \%){ }^{11}$

Perbandingan jumlah penderita retardasi mental berjenis kelamin laki-laki dan perempuan 1:1 yang didapatkan pada penelitian ini, juga memiliki perbedaan dengan penelitian yang dilakukan oleh Ana Ferlina pada tahun 2014 pada anak tunagrahita di yayasan Setia Ayah Bunda Kota Payakumbuh yang menyatakan bahwa perbandingan jumlah penderita laki-laki dengan perempuan adalah 1,5:1.14 Perbedaan rasio jenis kelamin pada penderita retardasi mental pada penelitian ini dikarenakan teknik pengambilan sampel pada penelitian ini tidak menggunakan total sampling karena keterbatasan yang dimiliki peneliti.

Berdasarkan hasil penelitian mengenai derajat retardasi mental didapatkan bahwa frekuensi terbanyak terdapat pada derajat ringan, dimana dari 46 sample diperoleh 23 anak memiliki rentang IQ 50-55 sampai dengan 70-75. Penelitian ini sejalan dengan penelitian yang dillakukan di SLB Semarang didapatkan hasil analisa IQ dijelaskan bahwa $8(10,7 \%)$ siswa memiliki tingkat intelektual borderline; 2 $(2,7 \%)$ siswa dengan tingkat intelektual 
rata-rata bawah; $35(46,7 \%)$ siswa dengan retardasi mental ringan; 29 (38,7\%) siswa dengan retardasi mental sedang; 1 $(1,3 \%)$ siswa dengan retardasi mental berat. ${ }^{15}$

Hasil penelitian yang telah dilakukan oleh Paulus Anwar Gazali terhadap 20 penderita retardasi mental yang juga dilakukan pemeriksaan test IQ didapatkan bahwa tingkat IQ rata-rata sampel adalah 43, yang sesuai dengan klasifikasi derajat retardasi mental sedang. Perbedaan hasil penelitian ini dapat disebabkan oleh karena penelitian yang dilakukan Paulus memiliki jumah sampel yang lebih sedikit. ${ }^{16}$

Berdasarkan hasil penelitian tentang usia ibu saat hamil pada penderita retardasi mental, diperoleh bahwa rentang usia ibu terbanyak adalah lebih dari 35 tahun, dengan frekuensinya 16 orang (34,8\%), yang kemudian diikuti oleh rentang usia berturut-turut 31-35 tahun $(30,4 \%), 26-30$ tahun $(21,7 \%)$, dan 21-25 tahun (13,1\%). Beberapa penelitian terdahulu hanya menjelaskan bahwa usia ibu saat hamil memiliki hubungan yang erat dengan kelahiran bayi dengan sindrom Down yang merupakan salah satu bentuk retardasi mental berat, seperti penelitian yang dilakukan di Semarang pada tahun 2008, ditemukan bahwa frekuensi usia ibu saat melahirkan dengan kejadian sindrom Down terbanyak adalah antara usia 36 40 tahun (31,57\%) dari 19 penderita. ${ }^{17}$

Penelitian serupa juga pernah dilakukan oleh Situmorang pada tahun 2011 di Surakarta dengan sample $20 \mathrm{ibu}$ yang memiliki anak sindrom Down, didapatkan hasil bahwa rerata usia ibu saat melahirkan sekitar 37,82. ${ }^{18}$ Dari beberapa penelitian tersebut dapat diketahui bahwa semakin tua usia ibu saat hamil akan memperbesar risiko memiliki anak dengan retardasi mental.

\section{SIMPULAN}

Frekuensi penderita retardasi mental yang berjenis kelamin laki-laki sama dengan yang perempuan. Derajat retardasi mental berdasarkan tingkat IQ penderita retardasi mental sebagian besar berada pada derajat ringan. Usia ibu saat hamil pada penderita retardasi mental sebagian besar pada usia lebih dari 35 tahun, dan terjadi kenaikan frekuensi seiring peningkatan usia ibu saat hamil.

\section{DAFTAR RUJUKAN}

1. American Association on Mental Retardation. The AAMR definition of mental retardation. Washington DC: AAMR. 2002. Tersedia pada www.AAMR.org. Diunduh pada tanggal 10 Mei 2014.

2. Maslim R. Diagnosis gangguan jiwa, rujukan ringkas PPDGJ III. Jakarta: Bagian ilmu kedokteran jiwa FK Unika Atma Jaya. 2001.

3. Chelly J, Khelfaoui M, Francis F, Cherif B, Bienvenu T. Genetics and pathophysiology of mental retardation. European J Hum Genet. 2006;14:701-13.

4. Kementerian Kesehatan RI. Pedoman pelayanan kesehatan anak di sekolah luar biasa (SLB) bagi petugas kesehatan. 2010.

5. Nevid JS, Rathus SA, Greene B. Psikologi abnormal Jilid 2. Edisi ke lima. Jakarta: Erlangga. 2005.

6. Ahuja AS, Thapar A, Owen MJ. Genetics of mental retardation. Indian $J$ Med Sci. 2005;59(9):407-17.

7. Vanagaite LB, Taub E, Halpern GJ, Drasinover V, Magal N, Davidov B, et al. Genetic screening for autosomal recessive non syndromic mental retardation in an isolated population in Israel. European J Hum Genet. 2007;15:250-3.

8. Allen EG, Freeman SB, Druschel C, Hobbs CA, O'Leary LA, Romitti PA, et al. Maternal age and risk for trisomy 21 assassed by the 
origin of chromosome nondisjunction : a report from the Atlanta and National Down Syndrome Projects. Hum Genet. 2009;125(1):41-52.

9. Sadler TW. Embriologi kedokteran langman. Jakarta: EGC. 2009.

10.Dinas Pendidikan Provinsi Sumatera Barat. Informasi pendidikan khusus dan pendidikan layanan khusus Provinsi Sumatera Barat. 2014.

11.Ramawati D. Faktor-faktor yang berhubungan dengan kemampuan perawatan diri anak tuna gahita di Kabupaten Banyumas Jawa Tengah. Skripsi, Universitas Indonesia. 2011.

12.Kaplan HI, Sadock BJ, Grebb JA. Sinopsis psikiatri ilmu pengetahuan perilaku psikiatri klinis. Tangerang: Binarupa Aksara Publisher. 2010.

13. Agradi P. Skrining sitogenetika pada anakanak retardasi mental di SLB Negeri Semarang. Karya Tulis IImiah, Universitas Diponegoro. 2008.

14. Ferlina A. Pengaruh terapi bermain: cooperative play dengan puzzle transportasi terhadap perkembangan sosial pada anak tunagrhaita di yayasan pendidikan "setia ayah bunda" kota Payakumbuh tahun 2014. Skripsi, Universitas Muhammadiyah Sumatera Barat. 2014.

15. Alresna F. Karakteristik dismorfologi dan analisis kelainan kromosom pada siswa retardasi mental di SLB C/C1 Widya Bhakti Semarang. Skripsi, Universitas Diponegoro. 2009.

16. Gozali PA. Analisis dismorfologi, sitogenetik dan tingkat IQ pada penderita retardasi mental di SLB Kecamatan Semin Kabupaten Gunung Kidul. Tesis, Universitas Diponegoro. 2008.

17.Andriati VB. DIstribusi kelainan kromosom sindrom Down dan usia ibu saat melahirkan di SLB Negeri Semarang. Skripsi, Universitas Diponegoro. 2008.

18.Situmorang C. Hubungan sindrom Down dengan umur ibu, pendidikan ibu, pendapatan keluarga, dan faktor lingkungan. Skripsi, Universitas Sebelas Maret. 2011. 